\title{
The impact of economic policy and structural change on gender employment inequality in Latin America, 1990-2010
}

\author{
Elissa Braunstein \\ Department of Economics, Colorado State University, Fort Collins, CO, USA \\ Stephanie Seguino \\ Department of Economics, University of Vermont, Burlington, VT, USA
}

\begin{abstract}
Latin America experienced a decline in household income inequality in the 2000s, in sharp contrast to growing inequality in other regions of the world. This has been attributed to macroeconomic policy, social spending, and increased returns to education. This paper explores this issue from a gender perspective by econometrically evaluating how changes in economic structure and policy have impacted gendered employment and unemployment rates, as well as gender inequality in these variables, using country-level panel data for a set of 18 Latin American countries between 1990 and 2010. Three variables stand out as having consistent gender-equalizing effects in the labor market: social spending, minimum wages, and public investment. Less important or consistent were the effects of external factors (such as terms of trade), economic structure, and GDP growth.
\end{abstract}

Keywords: Latin America, gender, labor markets, minimum wage, government spending

JEL codes: $J 16, J 21, E 02, H 53, J 48, O 54$

\section{INTRODUCTION}

After about a decade of relatively strong economic growth, most Latin American economies are struggling to emerge from the global growth slowdown, evident since 2009, and the ripple effects of the end of the commodity price boom. From a human development perspective, this is a particularly troubling turn of economic fortunes because the boom of the early and mid 2000s, a real departure from the crises of the 1980s and the doldrums of the 1990s, was accompanied by significant declines in household income inequality across the region. This was especially noteworthy, occurring in a region that has historically been among the world's most unequal and at a time when inequality was widening globally. Though the growth slowdown in 2009 has not yet reversed the declining inequality trend of the 2000s, it may be too soon to tell if that declining trend is structural or cyclical. It is thus all the more important to understand its causes, and whether and how more challenging economic conditions may subvert the social and economic progress achieved over the last decade. ${ }^{1}$ A number of scholars have taken up this question,

1. From 2009-2013, inequality, whether measured as the net or market Gini, fell in 13 of the 18 countries in our sample, despite the growth slowdown, based on authors' calculations from the Solt (2016) database (accessed 31 January 2017). 
focusing on both the political (the rise of left-of-center governments) and the economic (macroeconomic and social policies) as casual factors, and relying primarily on the net household Gini coefficient (post-tax and -transfer) to measure inequality (Cornia 2014; Lopez-Calva and Lustig 2010; Tsounta and Osueke 2014).

A related but as yet unevaluated question is whether gender inequality also declined in the 2000s and if so, whether the economic determinants are similar to those identified in the empirical literature on household inequality. Considering gender inequality separately from income inequality is important because income is not always equitably shared at the household level. Research on intrahousehold resource distribution identifies distinct gender differences in access to and control over resources, indicative of non-pooling of income. Gender equality is also an important development goal in itself, not least because of the association between a number of gender equality measures (for example, health, education, and employment) and higher rates of economic growth. Time series data on the gender distribution of income at the household level do not exist, so in this paper we focus on differences in economic opportunity as reflected in employment and unemployment rates. These measures of economic opportunity are important because earning an income through employment is a crucial vector for women's economic empowerment, one that has lagged behind the substantial achievements in gender equality in health and education throughout the region. Moreover, our focus on gender-specific labor market outcomes indicates whether and how changes in economic policy and structure affect more than household income, and whether these changes contribute to creating the conditions for sustainable and transformative improvements in well-being and gender equality. Taking as a guide the empirical literature exploring income inequality trends in Latin America, we econometrically evaluate how changes in economic policy and structure have impacted gendered employment and unemployment rates, using country-level panel data for a set of 18 Latin American countries between 1990 and $2010 .^{2}$

\section{GROWTH, HOUSEHOLD INCOME INEQUALITY, AND POVERTY}

Despite some stark country-level differences, Latin America's overall GDP growth record was much better in the 2000s than the 1990s. For the region as a whole, annual real per-capita growth averaged 3.8 percent during the expansionary period 2003-2008. During the business cycle prior to that, 1990-2002, per-capita growth averaged only 2.2 percent during the expansionary years of 1990-1997, before declining to an annual average of only 0.2 percent in 1998-2002 when the fallout from the Asian financial crisis spurred what was later referred to as the 'lost half-decade.' With the collapse in consumer demand that accompanied the global economic crisis in 2008-2009 (this time emerging in advanced economies), growth declined to -1.8 percent in 2009 in the region, rebounding to 3.5 percent in $2010-2013$ but then slowing to 1.4 percent in $2014-2015$ as the collapse of global trade and falling commodity prices firmly took hold. ${ }^{3}$

2. The country sample includes: Argentina, Bolivia, Brazil, Chile, Colombia, Costa Rica, Dominican Republic, Ecuador, El Salvador, Guatemala, Honduras, Mexico, Nicaragua, Panama, Paraguay, Peru, Uruguay, and Venezuela.

3. Authors' calculations based on data from WDI database, accessed 29 January 2017. Growth based on real local currency, not weighted by population. 
That most countries in the region experienced sustained increases in growth for much of the 2000s is certainly an important and positive development. But the substantial declines in inequality and poverty that accompanied this higher growth are especially significant and promising from a well-being perspective. Figure 1 (overleaf) illustrates both market and net household income Gini indices by sub-region from 1990 to $2013 .{ }^{4}$ From 1990 to 2002, inequality increased in all sub-regions, with the largest increase in the Andean region (which registered a 13.2 percent and 7.6 percent increase in the market and net Ginis, respectively). In contrast, from 2002 to 2013, there are notable declines in the Gini indices in all sub-regions. Here, too, we see the largest changes in the Andean region with the market and net Gini falling 13.4 percent and 14.8 percent, respectively (although there is a small increase in the net Gini from 2012 to 2013). One of the reasons that declining inequality as measured by the Gini index is so encouraging is because it was accompanied by declines in poverty, suggesting that inequality decreased partly via improving the lot of the poor (Braunstein et al. 2015).

Gini coefficients based on household surveys may not fully describe the degree of inequality within countries because they collapse men's and women's income and thus obscure trends in the degree of gender inequality. Also, measurement problems in household surveys occur due to the omission of income sources for the very wealthy. An alternative measure, the functional distribution of income, can overcome this problem. Data for Latin America show that the wage share of income, defined as the ratio of labor compensation to gross value added, has declined since the early 1980s, with no upward trend in the 2000s, in contrast to the Gini based on household surveys (Rodriguez and Jayadev 2010). The wage share of income does not, of course, capture redistribution via social expenditures and tax policies. But changes in labor shares do shed light on structural and political economy factors that contribute to changes in interpersonal inequality, and should be taken into consideration in conjunction with the Gini and gender equality indicators.

The decline in household income inequality and poverty rates suggests that the economic boom in the 2000s in Latin America was more widely shared than in previous eras. Given declines in the wage share, one inference, however, is that improvement in the Gini is primarily attributable to social policies rather than income-equalizing structural changes, indicating the importance of considering labor market outcomes directly.

\section{EVALUATING THE ROLE OF GOVERNMENT POLICY, MACROECONOMIC STRUCTURE, AND GLOBAL ECONOMIC CONDITIONS}

The good economic news of the 2000s coincided with progressive political changes in the Latin American region. A number of what we (and others) refer to as left-of-center (LOC) governments were democratically elected, ushering in a new era of reform in economic and social policy. At the same time, favorable global economic conditions lowered the 'price' of reform, and scholarly debates on the relative importance of political regime versus a variety of macroeconomic policies and circumstances in lowering

4. Data are from Solt (2016). A number of studies have used the Inequality and Development in Latin America (IDLA) data set, which includes both net (for wage earners) and gross (for the self-employed who pay taxes) income. Broad patterns are similar between the two data sets, but the Solt data set has greater coverage. 
310 Review of Keynesian Economics, Vol. 6 No. 3

(a) Market Gini

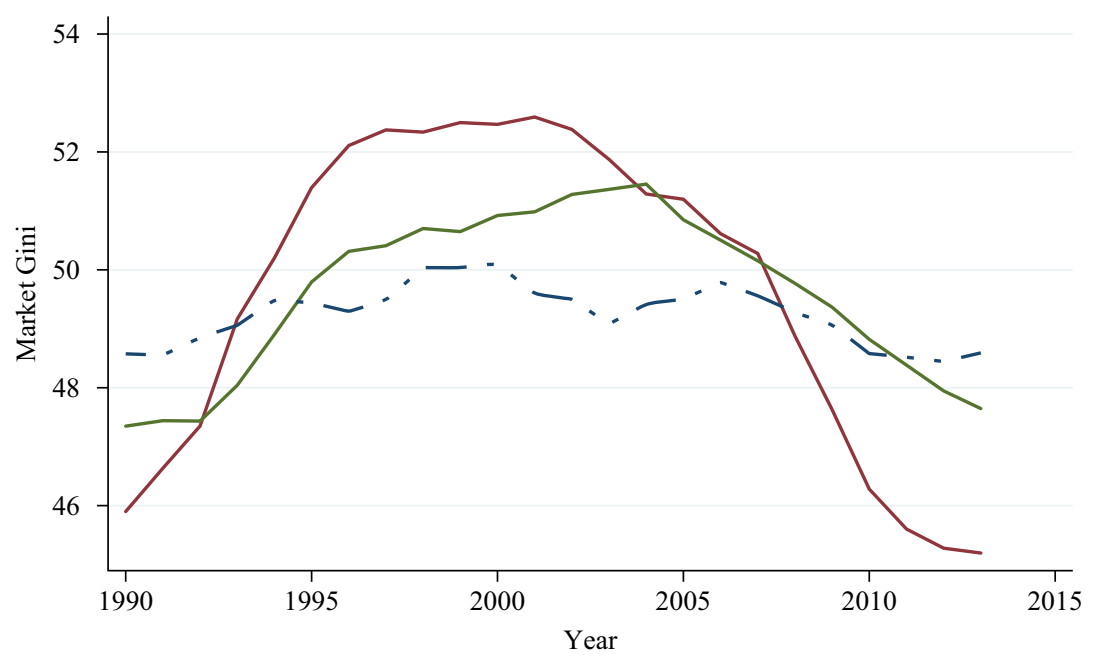

$-\cdots-$ Central America \& Mexico — Andean region Southern Cone

(b) Net Gini

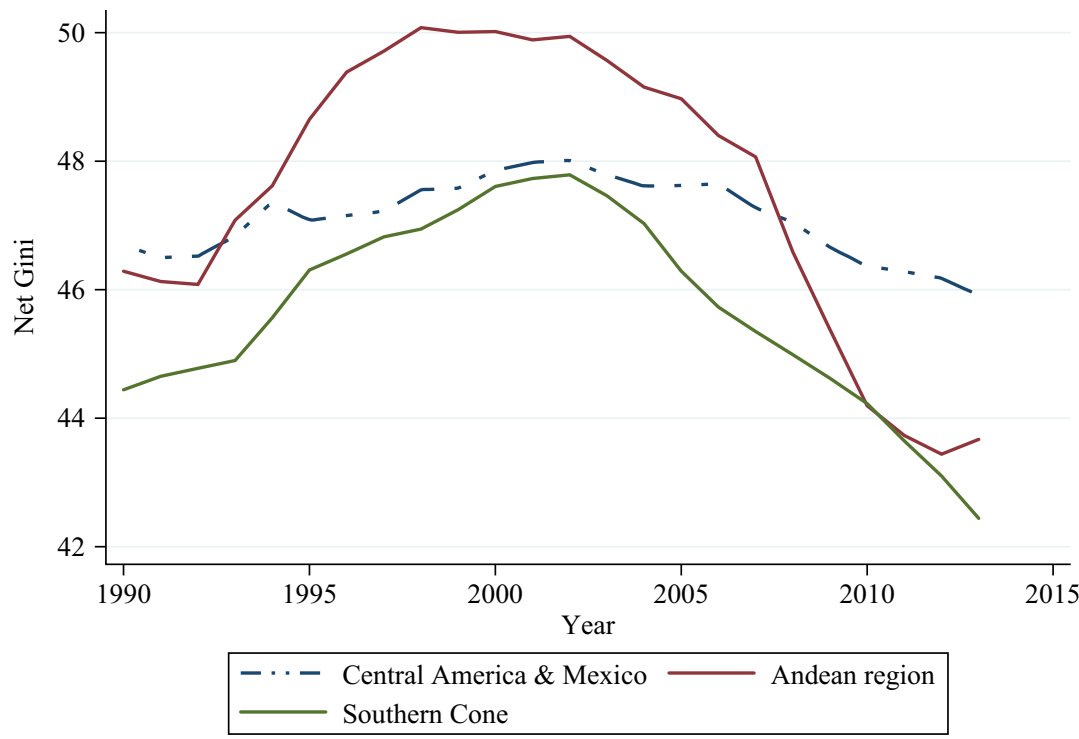

Note: Market Gini is pre-tax and -transfer; net Gini is post-tax and -transfer. Data for 1990 and after 2009 are not available for Nicaragua. Central America \& Mexico includes: Costa Rica, Dominican Republic, El Salvador, Guatemala, Honduras, Mexico, Nicaragua, and Panama. Andean region includes: Bolivia, Colombia, Ecuador, Peru, and Venezuela; Southern Cone includes: Argentina, Brazil, Chile, Paraguay, and Uruguay.

Source: Authors' calculations from Solt (2016), accessed 30 January 2017.

\section{Figure 1 Income Gini index by region}


household income inequality and promoting shared growth ensued. The deterioration of those global economic conditions since the Great Recession, especially the fall in commodity prices, and the spread of recession throughout the region have accompanied leftist losses in a number of Latin American countries. This makes the task of understanding the causal factors behind declining inequality all the more important, as changes in both economic conditions and government policy may reverse the gains achieved since the early 2000s.

The core pillars of LOC macro policy emphasized macro stability, fiscal prudence, and free trade and capital flows, a stance that is essentially the same as the standard orthodox prescriptions (Cornia 2010; Madrid et al. 2010; Ocampo and Vallejo 2012). In contrast to more neoliberal regimes, however, the global macro stance in LOC governments was designed to protect the domestic economy from the instabilities of global financial integration. Policies included management of real exchange rates to maintain competitiveness and stability, accumulation of international reserves to assist in managing exchange rates, and reduction of external indebtedness and dependence on foreign capital for borrowing (Cornia 2010; Damill and Frenkel 2014; Ocampo 2007). On the fiscal front, governments increased emphasis on engaging in neutral or counter-cyclical fiscal policy, though the desire to maintain budget balance has been a constraint across all types of governments (Cornia 2010; Ocampo 2007). It should be noted that a number of non-LOC governments in the region also adopted similar policies, and global economic conditions - increasing terms of trade and global demand for natural resource commodities, greater availability of external finance as interest rates sagged in the global North, and increasing migrant remittances - made 'good' macro policy easier to conduct.

LOC governments also demonstrated a willingness and aptitude for using social and labor policies to lower inequality and poverty (Barrientos 2014; Ocampo and Vallejo 2012). Labor market policy reforms included real minimum wage increases and efforts to increase formalization (Keifman and Maurizio 2014). Indeed, a variety of governments in Latin America - not just LOC governments - began to experiment with progressive social programs such as expanding and de-privatizing pension coverage and maintaining conditional cash transfers, perhaps reflecting widespread disappointment with the neoliberal reforms of the 1980s and 1990s as well as greater confidence in government capacity and the social contract (Cornia et al. 2011). In fact, there was much more movement on social than labor market policy.

A number of econometric studies explore the link between government policies, salutary economic conditions, and the decline in household income inequality. A brief overview of this work gives us a sense of the macroeconomic dynamics of household income inequality in Latin America, an essential point of reference in thinking about gender.

Cornia et al. (2011) analyse the impact of fiscal policy, measured as the ratio of direct to indirect taxes and social protection spending, on the Gini coefficient. The former is negatively correlated with inequality, indicating that efforts to make tax systems more closely linked with income than consumption have had progressive income effects. The effect of social protection was found to be statistically insignificant, however, probably because social protection spending includes both social assistance and social security, and the latter is only slightly progressive. That is because this spending is concentrated among formal sector workers, a group that is already well-situated in terms of income (Cornia 2014). Of the other control variables included in the analysis, only GDP growth and the education Gini are statistically significant correlates of income inequality, while the minimum wage index as a share of per-capita GDP is not. 
Another set of econometric studies explicitly evaluates the impact of political regime on household income inequality as measured by the Gini index. The general conclusion is that LOC governments are associated with larger declines in inequality, even after controlling for public policies, global economic conditions, and economic structure (Birdsall et al. 2013; Cornia 2014; McLeod and Lustig 2010). Cornia (2014) also finds that economic growth has modest progressive effects on household income distribution although social expenditures, the ratio of direct to indirect taxes, the distribution of education, and the minimum wage index (multiplied by the percent of total employment in the formal sector) has even stronger effects. ${ }^{5}$ Global economic conditions have less of an impact on declining inequality, with the strongest effects coming from terms of trade (progressive).

Braunstein et al. (2015) analyse the correlation between government type in Latin America and a composite gender equality index consisting of employment, unemployment, urban wages, poverty, informality measures, and a macroeconomic policy index. They too find that governments from the center and center-left achieved greater improvements in gender equality from 1990-2010 as compared to center-right governments.

A new set of studies has taken a longer-term view, using a variety of methodologies to assess whether there has been some structural change in Latin American inequality dynamics independent of political regime, and asking whether it extends beyond income to other measures of human development (none of which are gender-specific) (Lopez-Calva et al. 2015). Several studies find that major contributors to lowering inequality post-2000 are decreasing returns to education, which compressed the skilled-unskilled wage gap, and the increasing terms of trade (Azevedo et al. 2013; Lustig et al. 2016; Szèkely and Mendoza 2015). Other factors such as declining dependency ratios, increased education, and lower tariffs are also important, but less so than declining returns to education and improving terms of trade.

This literature is instructive, especially the finding that social public expenditures, minimum wages, and the terms of trade all have progressive household income effects, while appreciated real exchange rates and fuel exports as a share of GDP tend to have regressive effects. But simply extending these findings to questions of gender inequality is problematic. For instance, with regard to the finding that social public expenditures lower household income inequality, the gender effects of such policies, particularly conditional cash transfer programs, have been questioned (Molyneux 2007). These programs in general condition income supports on children's school attendance, participation in parent-teacher meetings, and nutrition and health education sessions, as well as doctor visits for immunizations. Because of gendered norms, it is primarily women who perform the unpaid tasks of fulfilling conditions required to access program payments. Such programs may actually reduce women's relative access to income and gender equality, even as children's status improves. Thus, we are reminded of the limits inherent in focusing solely on household-level income inequality. Attention to gender differences in employment and unemployment will give us a sense of how changes in both social and economic policy, as well as structure, have affected gendered labor markets.

5. Note that the variable for social expenditure differs from the social protection measure used in Cornia et al. (2011), where the latter includes only social security and social assistance, while the former is a wider measure including spending on health and education. We use social expenditure in our analysis. 


\section{GENDER INEQUALITY IN ECONOMIC OPPORTUNITIES}

We focus on differences in employment and unemployment, as opposed to, for instance, gender inequality in capabilities such as health or education. This is partly because there is not much inequality to explain in the capabilities domain, at least as measured by the standard variables. The ratio of female to male education is close to parity in Latin America, for example, and in the Southern Cone, women's average educational attainment now exceeds men's. Conversely, Latin America has lagged behind other developing regions, such as East and Southeast Asia, in women's relative access to economic opportunities (Seguino 2016).

Figure 2 (overleaf) provides trend data by sub-region on secular trends in the ratio of female-to-male employment-to-population rates (hereafter referred to as women's relative employment) and unemployment rates. The employment-to-population ratio and the unemployment rate are inversely related but are not perfectly correlated. The first is a measure of the proportion of the working age population that is employed (whether or not a person declares him or herself to be an active labor market participant). The unemployment rate is a measure of the proportion of labor market participants who cannot find employment. There is a gender dimension to these two variables. Women are less likely than men to be in the labor force due to gender norms, such as household responsibilities. As a result, women's relative unemployment rate may be artificially lower than it would otherwise be. The ratio of femaleto-male employment rates captures differences in women's and men's access to work for the working age population, regardless of how a person defines their labor market status. It is therefore a more precise measure of gender differences in employment (though it tells us nothing about the quality of that work, including the pay).

Relative employment ratios are generally low but increasing over time (Figure 2a), with women's relative employment in the Andean region increasing by 38.5 percent from 1990 to 2013, the most rapid of all regions. The increase in women's relative employment is only partially due to the increase in women's employment rates. Over the last two decades, men's employment-to-population ratio fell in two subregions, Central America \& Mexico and the Southern Cone, by 1.6 percent and 2.7 percent respectively. There thus may be a gender conflictive component to improvements in gender equality in employment in some countries.

Figure $2 b$ shows women's relative unemployment. The secular trend over time exhibits much more variability than the relative female employment rate. In the Southern Cone, the relative female unemployment rate has risen since 1990, although it begins to decline in 2009. The pattern there is attributable to the gender-differentiated unemployment effects associated with the 2008-2009 economic crisis in Southern Cone countries, where women's relative unemployment was 13.6 percentage points higher in 2008-2009 than in the 2000s as a whole. Central America and Mexico experienced the most substantial decline in the female-to-male unemployment rate, 22 percent since 1990.

In sum, the data in Figure 2 portray something of a mixed picture on progress in women's relative labor market outcomes as measured by changes from 1990 to 2013. The strongest and most uniform category is employment, with women's relative employment rates increasing throughout the Latin American region. Conversely, women's unemployment has tended to increase relative to men's in some countries. This suggests a contradictory picture of the course of gender inequality in economic opportunity since the 1990 s, so it is important to investigate multiple dimensions when analysing causal factors and effects. 
314 Review of Keynesian Economics, Vol. 6 No. 3

(a) Female-to-male employment rate ratio

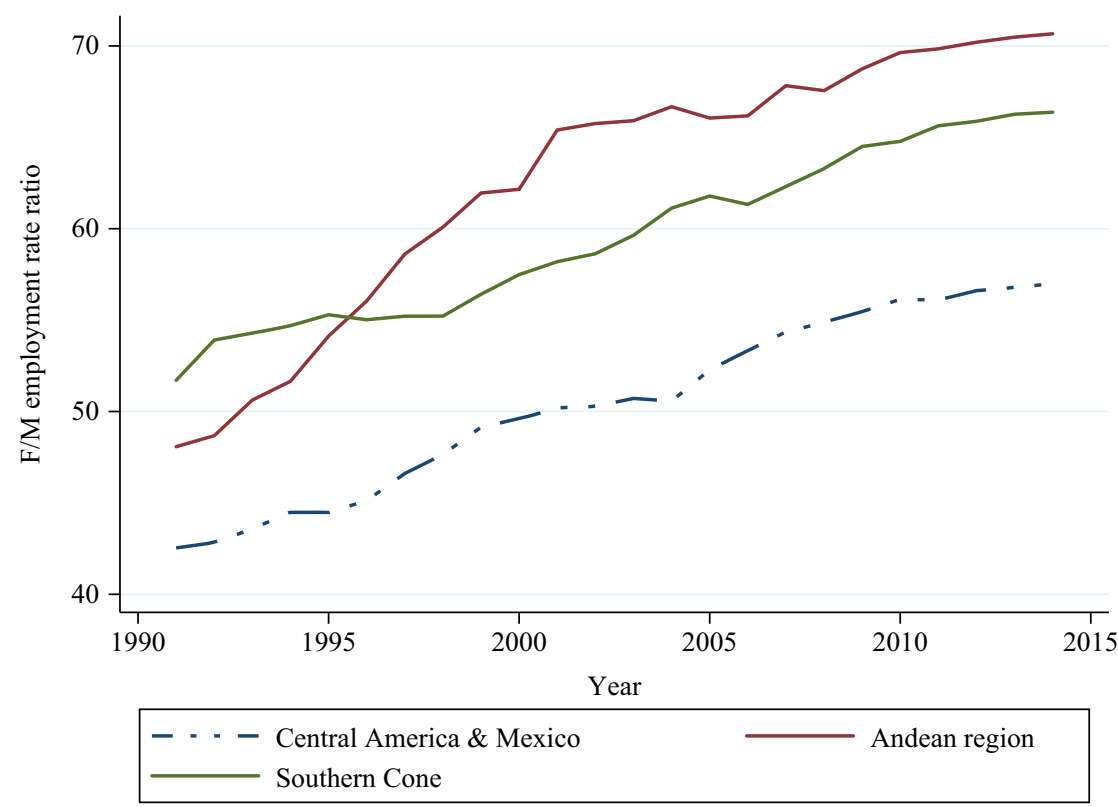

(b) Female-to-male unemployment rate ratio

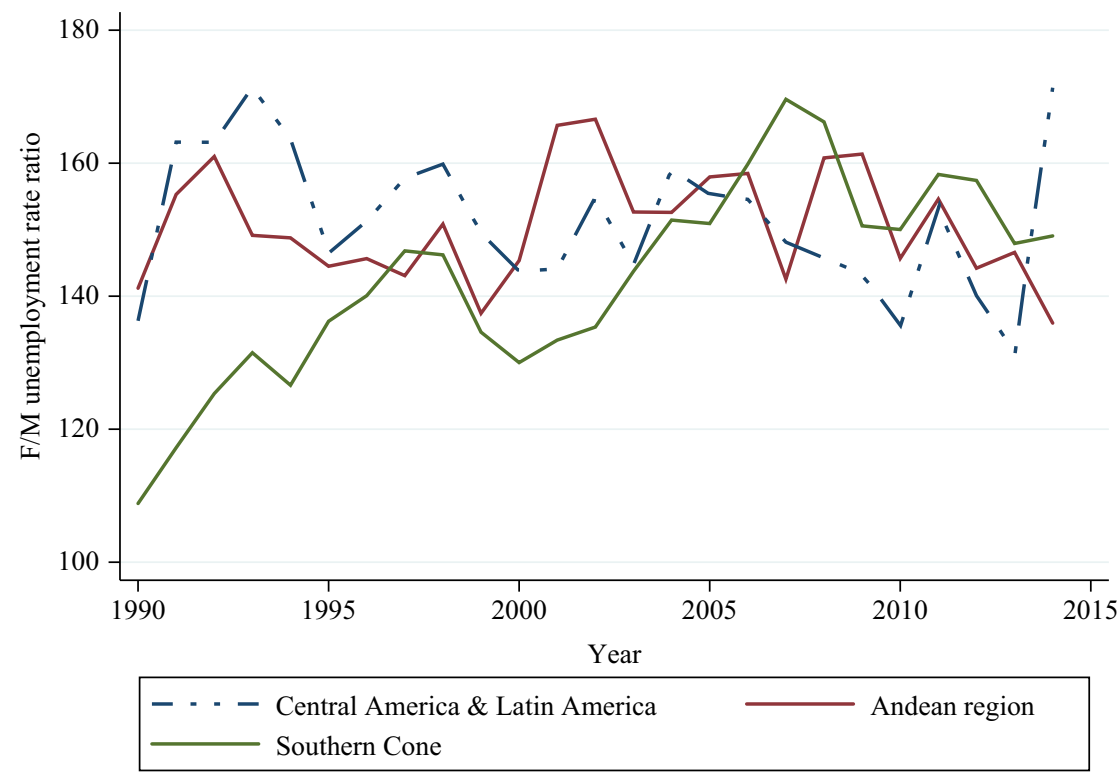

Note and source: The ratios of female-to-male employment-to-population (15 and older) and unemployment are calculated from World Development Indicators database, accessed 31 January 2017.

Figure 2 Trends in female-to-male employment and unemployment rates by region, 1990-2015 


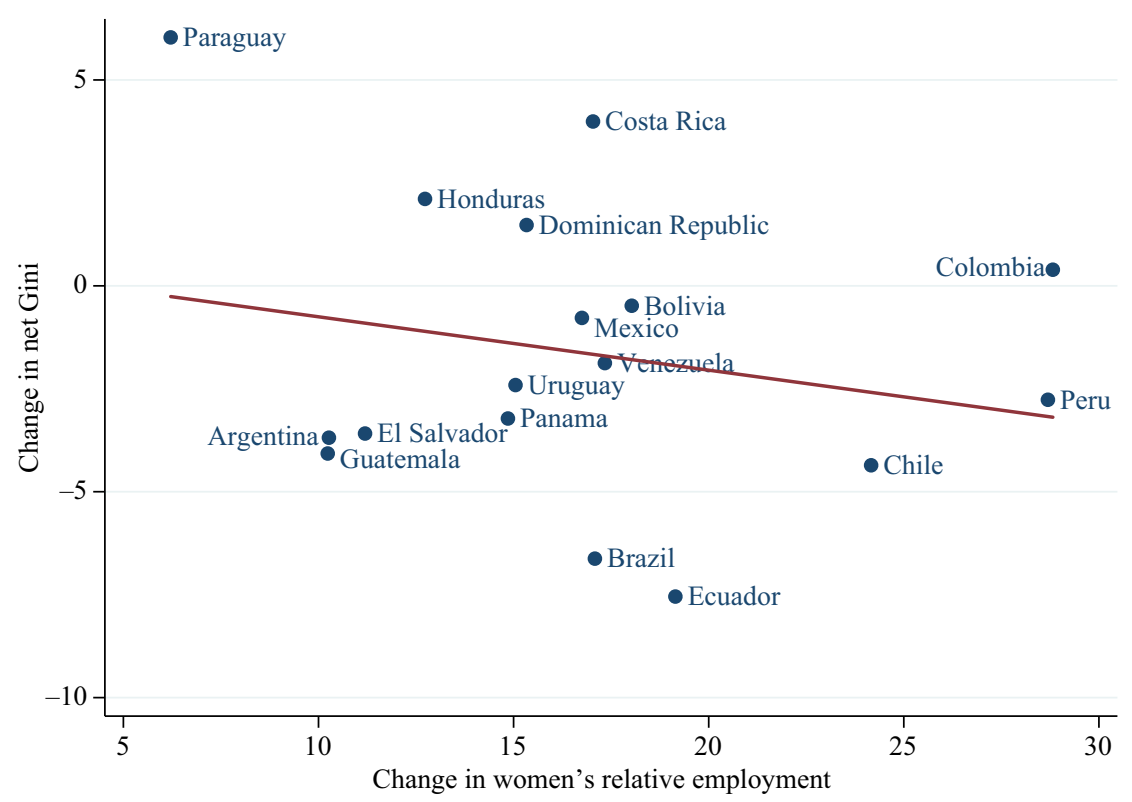

Note and source: Authors' calculations based on data from Solt (2016) and World Development Indicators. Changes refer to percentage point difference (for women's relative employment) and absolute difference (for net Gini) between the average values from 1991 to 2013; Nicaragua is omitted because of missing net Gini data after 2009.

Figure 3 Changes in women's relative employment and net Gini, 1991-2013

As noted earlier, declines in household income inequality as measured by the Gini coefficient may differ from trends in gender equality. We conduct a comparison of the correlation of these two variables by examining the change in the net Gini index from the early 1990s to the late 2000s as compared to the change in the ratio of women's to men's employment, the most consistently gender-equalizing category in Figure 2. Figure 3 is a scatter-plot for the two series, and shows a negative correlation between them (the correlation coefficient is -0.22 ), indicating that countries with the largest reduction in household income inequality also experienced the greatest improvements in women's relative employment rates, though there is notable dispersion around this central trend. Interestingly, limiting the time span to the 2000s, when most of the decline in household income inequality occurred, lowers the correlation to 0.04 , suggesting that the drivers of income inequality differ from those of women's relative employment, and that the two trends should be investigated separately.

\section{ECONOMETRIC ANALYSIS}

\subsection{Model}

We now turn to an econometric analysis of the effect of macro-level variables on gender equality using three sets of explanatory variables: (i) social and employment policies; (ii) macroeconomic policies; and (iii) measures of economic structure. 
One set of regressions analyses the determinants of the ratio of female-to-male employment rates, and separately, women's and men's employment rates. In a second set of regressions, we evaluate the determinants of women's and men's unemployment rates, as well as the ratio of the two.

One of the challenges in this type of analysis is potential multicollinearity: some of the independent variables may be correlated, making it difficult to isolate the individual effects of the independent variables. Capital account liberalization, for example, may lead to an increase in private capital flows, but this will also have an effect on the real exchange rate. Simultaneous inclusion of private capital flows and exchange rates as independent variables may therefore result in insignificant coefficients on one or both variables. This problem is in part due to the nature of macroeconomic variables, and a function of the limited time-series data available. One way to address this, and the approach we adopt, is to estimate a parsimonious reduced form equation to focus on the key macro phenomena that may contribute to gendered outcomes in employment and unemployment.

We employ two measures of social and employment policy: social public expenditures made by central governments as a share of GDP and the minimum wage relative to the average monthly wage. The motivation for including these two explanatory variables is as follows. Social expenditures that level gender inequalities may improve women's relative educational attainment and health or ease the time constraints associated with women's primary responsibility for reproductive work, permitting greater participation in employment. Social expenditures can also positively affect the relative demand for women's labor directly, as they contribute to expanding the social services sector, a traditional source of employment for women. On the other hand, the gender effects of some social expenditure programs such as conditional cash transfers have been questioned because of the demands they make on unpaid household labor time, largely fulfilled by women (Molyneux 2007).

Minimum wage increases may be gender-equalizing since women are over-represented in low-wage employment (Rubery and Grimshaw 2011). This can be a particularly useful tool in the face of gender job segregation shaped by norms and stereotypes that reduce women's bargaining power vis-à-vis employers relative to men. Standard economic theory predicts that higher minimum wages can lead to employment losses. There is, however, some empirical evidence to the contrary which suggests that higher minimum wages at worst have negligible effects and may even have positive effects on employment, resulting from the demand-side stimulus of higher wages and efficiency wage effects. Due to women's greater concentration in informal sector work than men throughout the region, minimum wage policy in Latin America has been more binding in informal than formal sectors (Cunningham 2007). We would therefore expect that if minimum wages have employment effects, they will differ by gender. Rather than using the minimum wage index as an explanatory variable, we employ a measure of the minimum wage relative to the average monthly wage to scale its relative significance across countries.

Our macro policy variables include the real effective exchange rate (REER), the real interest rate (the nominal lending rate minus the rate of inflation), and public investment as a share of GDP. ${ }^{6}$ The real exchange rate measures a country's competitiveness

6. Previous studies have included the fiscal balance as an explanatory variable. Because this variable is correlated with one of our independent variables, GDP growth, and due to the limited time series available, we have chosen not to include this variable in our regressions. We also ran regressions that included this variable in place of GDP and it was not statistically significant. 
relative to its trading partners; the more appreciated it is, the less competitive is domestic production. Macroeconomic policies can be important determinants of the real exchange rate. Real exchange-rate appreciation worsens the trade balance, potentially dampening GDP growth and job creation. Gender equality in employment may be negatively affected as a result, if resulting job losses are in sectors in which women workers are more concentrated.

Monetary policy affects the real interest rate and employment via the negative effect of the real interest rate on private investment, thereby contributing to a decline in employment. Whether such effects are gendered or not depends in part on the type of gender job segregation that exists. If men are more concentrated in interest-rate-sensitive industries, men's employment may be more strongly affected than women's.

Finally, under the category of macroeconomic policy, we examine the effect of public investment. Public investments have both direct and indirect employment effects. Physical capital investments raise the relative demand for men's labor because these industries tend to be male-intensive (for example, construction, transportation, or power). However, enhancing physical infrastructure such as electricity, water, sanitation, or transportation may have a significant impact on gendered access to employment if such investments reduce women's care burden (Agénor and Canuto 2012; Gammage 2010). The net effect on gendered employment outcomes will depend on the relative strength of these potentially contradictory effects.

A country's structure of production also has gender implications due to gender norms and stereotypes that contribute to gender job segregation. A large literature documents the rise in the female share of employment as economies shift production to labor-intensive manufactures, with women workers under-represented in capitalintensive industries such as mining and petroleum-related production activities. Furthermore, as an economy industrially upgrades, there is some evidence of a defeminization of manufacturing employment (Tejani and Milberg 2016). We use two explanatory variables to capture these effects. First, we include the ratio of manufacturing exports to imports as an explanatory variable, with the ratio assumed to rise as an economy moves up the industrial ladder. Second, we use fuel and ores as a share of merchandise exports. ${ }^{7}$ Theoretically, we would anticipate that as the share of fuels and ores in exports rises, men's employment outcomes would improve more than women's. However, these sorts of industries do not tend to generate much employment, and may even have Dutch Disease-type effects on other industries that typically employ men.

The terms of trade, which reflect the structure of imports and exports and their price and income elasticities, can have employment effects. Commodity price booms improve the terms of trade for commodity exporters, stimulating import demand for a given level of exports. The employment effects, however, are ambiguous. Insofar as an improvement in the terms of trade stimulates aggregate demand for domestically produced labor-intensive goods, women may differentially benefit from increased employment in the economy as a whole or in the agricultural sector. On the other hand, an improvement in the terms of trade may stimulate investment in male-dominated extractive industries. A second avenue by which gender equality may be affected is via the effect on government revenues, with commodity price booms leading to increases in publicsector revenues and expenditures, which may or may not be gender-equalizing.

Finally, although our primary interest is in the impact of macro policies related to social spending and labor markets, we must control for GDP growth. Growth could

7. We do not have data on fuel and ores as a percentage of GDP, and therefore use exports of these goods as a second-best proxy. 
also be equalizing if women more than men gain access to newly created jobs. There is evidence of a two-way causality between gender inequality and growth, with the strength and direction of those relationships mediated by the structure of an economy and the pattern of gender job segregation, an issue that becomes important for the econometric analysis and is discussed in more detail below (Costa et al. 2009; Klasen and Lamanna 2009; Seguino 2010). ${ }^{8}$

\subsection{Data}

The time period of our analysis is 1990 to 2010, due to limited coverage of key variables after 2010. Table 1 provides descriptive statistics for the sample variables; a full accounting of data sources and computations is provided in Appendix 1. In terms of statistical transformations and tests, most variables were converted into natural logs for ease of comparison of coefficients. Real interest rates and GDP growth were not so converted since these variables take on negative values. All variables were tested for stationarity using Fisher-type panel unit root tests with an augmented Dickey-Fuller specification

Table 1 Descriptive statistics for sample variables, 1990-2010

\begin{tabular}{lrrrrr}
\hline & Mean & Median & Std dev. & Min. & Max. \\
\hline Female-to-male employment & 55.0 & 53.5 & 9.5 & 37.0 & 79.9 \\
Female employment & 41.7 & 40.9 & 7.6 & 25.4 & 63.2 \\
Male employment & 75.8 & 75.7 & 5.2 & 61.4 & 88.1 \\
Female-to-male unemployment & 152.1 & 150.3 & 39.1 & 40.7 & 294.2 \\
Female unemployment & 11.2 & 10.1 & 5.8 & 1.4 & 30.6 \\
Male unemployment & 7.3 & 6.8 & 3.3 & 1.3 & 18.7 \\
Social spending/GDP & 12.2 & 10.4 & 5.5 & 3.6 & 27.8 \\
Min/avg wage & 39.8 & 35.7 & 16.9 & 16.3 & 104.8 \\
REER & 97.5 & 96.8 & 17.4 & 46.1 & 155.8 \\
Real interest rate & 14.1 & 10.2 & 17.5 & -97.5 & 93.9 \\
Public inv/GDP & 4.1 & 3.5 & 2.2 & 0.0 & 11.3 \\
Mfg X/M & 40.8 & 34.5 & 27.1 & 2.8 & 115.7 \\
Fuel \& ores/X & 23.2 & 11.5 & 25.3 & 0.2 & 94.4 \\
Terms of trade & 102.6 & 100.0 & 19.4 & 51.0 & 204.0 \\
GDP growth & 2.0 & 2.2 & 3.8 & -11.7 & 16.2 \\
\hline
\end{tabular}

Notes: All figures are in percent except for two indices - the real effect exchange rate (REER) (2005=100), and the terms of trade $(2000=100)$. Fuel and ores are measured as a share of merchandise exports. Employment and unemployment rates are relative to the share of the population aged 15 and older. For details on data sources and computational notes, see Appendix 1.

8. It would have been useful to include determinants of female and male labor supply in our model as measured by the age-dependency ratio (the ratio of young and old to working age population). The dependency ratio is a proxy measure of care burdens, which if differentially borne by women, can affect their ability to participate in paid labor markets. This variable, however, performed poorly and counter-intuitively, a finding also noted by Cornia (2010). This may be because the variable is poorly measured, or because our time series is so short. It was not possible to transform the dependency ratio in such a way as to obtain plausible coefficient estimates on this and other variables, and we therefore decided not to include it in our model, absent a better measure of care burdens. We note then that our estimates may suffer from omitted variable bias and should be viewed with caution. 
applied to the individual countries. The Fisher test was used because the panel is slightly unbalanced due to occasional missing observations. The test was performed with and without a deterministic time trend. All transformed variables were found to be stationary (results available on request).

\subsection{Estimation strategy}

To explore the determinants of gendered labor market outcomes in Latin America for the period 1990-2010, we employ two estimation techniques: ordinary least squares (OLS) and two-stage least squares (2SLS) using fixed effects panel estimation to control for country-specific factors not otherwise captured in our independent variables that may influence gender outcomes. ${ }^{9}$

Formally, the model we use is of the form:

$$
\text { Gender }_{i t}=\alpha+\beta X_{i t}+\mu_{i}+\varepsilon_{i t},
$$

where Gender is our gender variable of interest in country $i$ and year $t ; X$ is a vector of the ten independent variables identified in the previous discussion; $\mu$ is the timeinvariant country fixed effect; and $\varepsilon$ is the error term. This approach is useful in ascertaining whether there are common effects of the independent variables across this group of countries. To the extent we find common effects (statistically and economically significant coefficients on our independent variables), this allows us to generalize regionally about the gender effects of the independent variables.

Because the growth rate of GDP may itself be influenced by gender inequality and several independent variables (including the real interest and exchange rates), we use 2SLS to account for endogeneity. The excluded instruments are the growth rate of gross fixed capital formation (public and private) and the growth rate of average years of education in the population aged 15 and older to capture the contributions of physical and human capital expansion to GDP growth. ${ }^{10}$ These variables consistently show up as statistically significant in growth regressions, largely attributable to their productivity-enhancing effects. In addition, the remaining nine independent variables are also included as instruments in the first-stage equations for GDP growth.

\subsection{Discussion of results}

Table 2 (p. 320) shows regression results for female-to-male employment rates and female and male employment rates separately, while Table 3 (p. 321) reports results for the unemployment rate ratio, and female and male unemployment. We report fixed effect and 2SLS regression results (the first-stage results are provided in Appendix 2) that include all of our independent variables with the exception of public investment and fuel and ores as a percent of merchandise exports. We then report regression results that include these latter two variables. The reason we report results in this way is that

9. We report robust standard errors, and $F$-tests reveal in all cases that the fixed effect model is better than a pooled OLS model (with no country-specific intercepts).

10. Although growth regressions use a wide variety of additional variables to explain growth economic openness, geography, foreign direct investment, and life expectancy, among others - our focus in this paper is not on the determinants of growth but rather the array of factors influencing gendered labor market outcomes. 


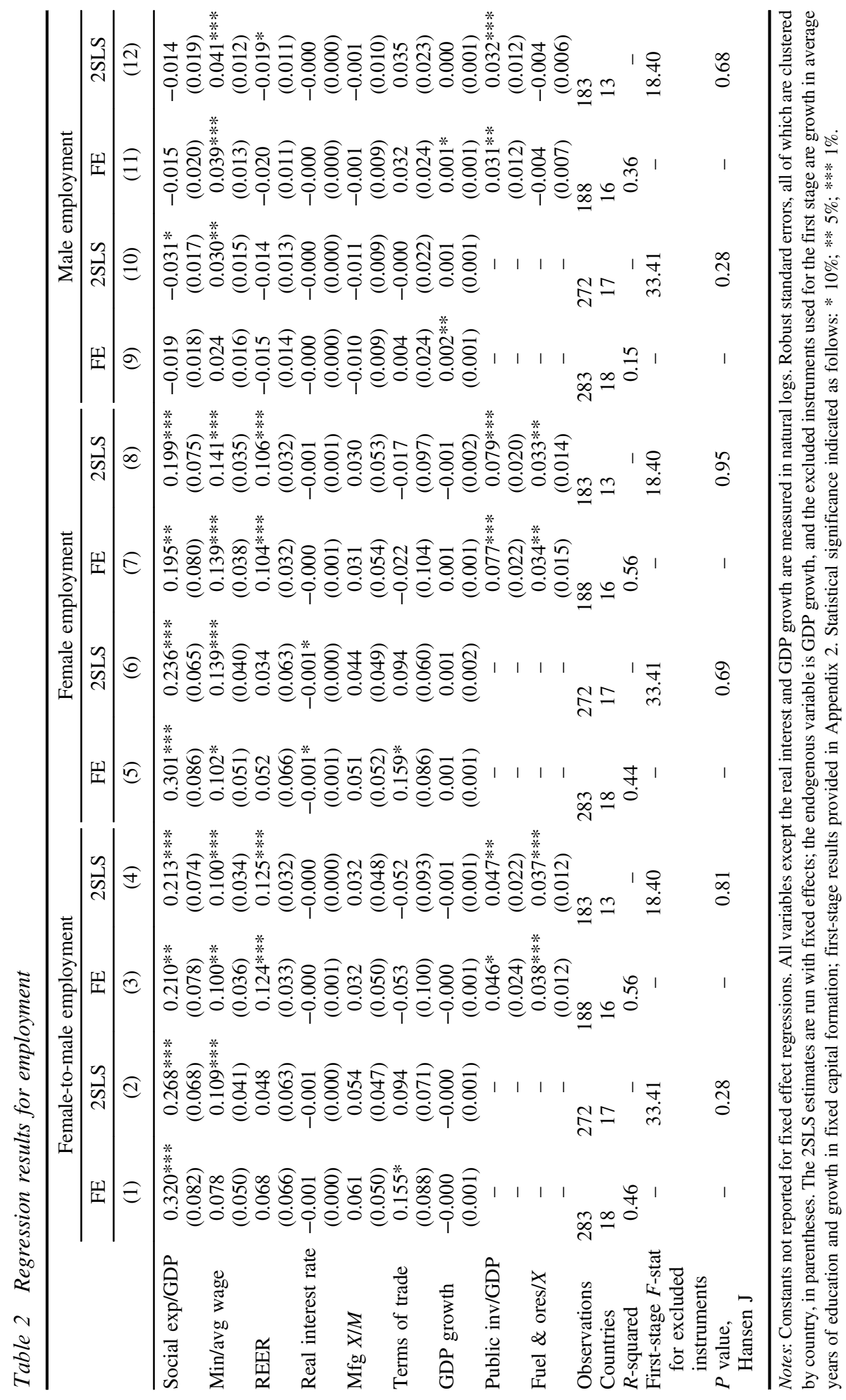




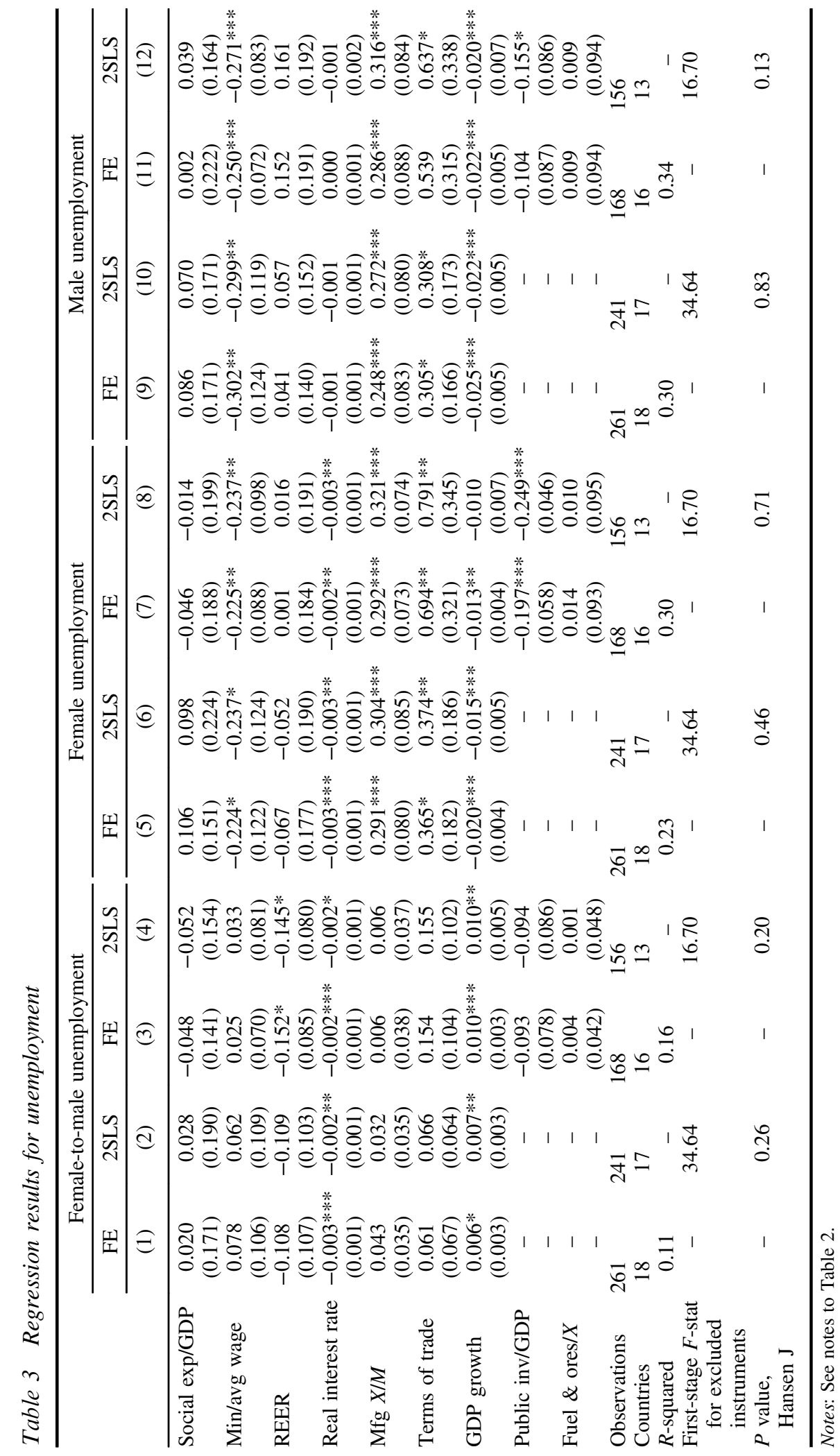


there is a large number of missing observations for the latter two variables, and two countries drop out of our regressions, Chile and the Dominican Republic. The results from the second set of regressions serve as a robustness check of the initial results. We use these to discuss a range of estimates rather than identifying a particular regression model as the correct one.

Table 2 also reports additional diagnostic test results. For the 2SLS equations, the first-stage $F$-statistic for excluded instruments is applied to the null hypothesis that the model is under- or weakly identified; all of these statistics surpass commonly applied critical values. ${ }^{11}$ The $P$-value for the Hansen $\mathrm{J}$ test of over-identifying restrictions indicates a failure to reject the null, implying that the instruments are valid in the sense of being uncorrelated with the error term and correctly excluded from the second stage equation. Most equations pass this test, but the unemployment results are weaker in this regard (Table 3, column 12). We report multiple specifications so that the results can be collectively used to obtain a sense of estimate range and stability.

Considering the determinants of employment (Table 2), the results indicate that a 10 percent increase in spending as a share of GDP (Social exp/GDP) is associated with a 2.1 to 3.2 percent increase in women's relative employment (columns 1-4). This magnitude is economically substantial and statistically significant across all specifications; its magnitude is also large relative to the other variable coefficient estimates. Taking a one-standard-deviation increase in social spending as a share of GDP (5.5 percentage points), which reflects a feasible change in social spending, the relationship shows even more potential for generating gender-equalizing change: women's relative employment would increase between 10.5 and 14.5 percent.

As we can see from the results on women's and men's employment in columns 5-8 and 9-12 respectively, these effects are the consequence of gains in women's employment, with few (if any) losses to men's employment. A one-standard-deviation increase in social spending is associated with a 9.8 to 13.6 percent increase in women's employment, with a maximal decline in men's employment of 1.4 percent (most of the estimates on men's employment are statistically equivalent to zero).

Despite some social programs that may increase women's care burdens, average social spending does not appear therefore to inhibit their employment. On the contrary, we present strong evidence that social spending encourages women's employment. On the other hand, there is some, albeit very weak, evidence that social spending may be negatively associated with men's employment. Though a full understanding of why this coefficient is negative would require deeper analysis, one possibility is that social spending that equalizes the playing field for women in terms of education, health, and income supports results in higher employment for women, some of which displaces men. Interestingly, social spending is also positively correlated with economic growth, as indicated by the first-stage regression provided in Appendix 1.

The minimum wage as a share of the average wage (Min/avg wage) also has a positive and significant effect on women's relative employment in all but column 1, though the size of that effect is smaller than social spending. A one-standard-deviation increase of the minimum-to-average wage ratio from the sample mean value (from 39.8 to 56.7 percent, for a change of 16.9 percentage points), increases women's relative employment by 4.2 percent (an average of the coefficient estimates in columns 1-4). Put another way, if a country with the lowest minimum-to-average wage ratio in the sample, 16.3 percent, increased that ratio to the mean value of 39.8 percent,

11. Staiger and Stock (1997) propose a rule of thumb that with one endogenous regressor, an $F$-stat of less than 10 indicates weak instruments. 
the associated increase in women's relative employment would average 13.7 percent. That is a very substantial change.

The results also indicate positive and statistically significant associations for women's (columns 5-8) and men's (columns 9-12) employment, though the impact is statistically and economically more significant for women than men. A one-standard-deviation increase in the minimum wage variable is associated with an average increase of 5.6 percent in women's employment and 1.4 percent in men's employment. Because men's employment rate is higher to begin with, the magnitudes of the gender-specific changes are closer in terms of the number of jobs generated. ${ }^{12}$

Overall, these results on the minimum wage contradict conventional hypotheses that higher minimum wages lead to employment losses, especially for the lowest wage earners, in this case women. On the contrary, our results indicate substantial employment gains, with stronger positive effects for women than men. One possible explanation is that lower-wage workers spend a higher share of their incomes on consumption, so boosting their wages positively impacts aggregate demand and generates employment. That this effect seems especially strong for women is a promising indicator of the potential for using labor market policy as a tool for both poverty alleviation and gender equality.

Turning now to macroeconomic policies, the REER is a positive and statistically significant correlate of women's relative and absolute employment in the more limited sample regressions that include public spending and fuel exports (columns 3, 4, 7, and 8). However, the effects are smaller and not statistically significant in the larger sample size regressions (columns 1, 2, 5, and 6). The estimates for men's employment are more consistent: small in magnitude and only significant in one specification. To better understand the different results that arose from the specifications with and without public investment and fuel exports, we re-ran the regressions after alternately dropping variables and countries. After dropping Venezuela from larger sample regressions (columns 1,2,5, and 6), the REER effect becomes positive and statistically significant (all at the 1 percent level), with the magnitudes in line with those reported in the extended equations. Given Venezuela's oil-intensive export profile, it is not surprising that it is an influential outlier in terms of the relationship between the REER and employment; interestingly, leaving it out does not affect the other coefficient estimates. The specifications with public investment and fuel actually include only a few observations on Venezuela because of limited data on public investment, hence it does not exert a strong influence on these results. For the remainder of the REER discussion, then, we utilize the coefficient estimates without Venezuela.

The REER results provide strong evidence of a positive association between exchange-rate depreciation (a higher REER) and women's employment, with coefficient estimates for women's relative employment ranging between 0.11 and 0.13 . A one-standard-deviation increase in the REER is thus correlated with a 2.0 to 2.4 percent increase in women's relative employment, driven by increases in women's employment, with little effect on men's. This result is consistent with the argument that depreciated real exchange rates can help generate employment for women, most likely via their effects on employment opportunities in tradable

12. For instance, in a country with a working-age population of 30 million (about the size of Argentina), a one-standard-deviation increase in the minimum wage as a share of the average wage is associated with 345000 more jobs for women, and 165000 more jobs for men. So women gain about twice as many jobs - fewer than the ratio of the coefficient estimates would seem to indicate. 
sectors. It also means that appreciated real exchange rates, as is often the case for economies experiencing large financial inflows or a commodity-price boom, weaken women's employment prospects.

The results for the real interest rate are weak and inconclusive. There is some evidence of a negative association for women's employment, though the magnitudes are not large enough to manifest in the equations for women's relative employment and the statistical significance is weak.

Looking at the results for public investment as a share of GDP (Public inv/GDP), there is a positive correlation for women's relative employment. Both women's and men's absolute employment increase but women's increases more than men's. The coefficient estimates are statistically significant. A one-standard-deviation increase from the mean that increases public investment from 4.0 to 6.2 percent of GDP is associated with an increase in women's relative employment of 2.5 percent, with women's employment increasing over 4.0 percent and men's by 1.7 percent. The category of public investment is a highly aggregate one. The type of public investment is likely to affect men's and women's employment differently. Capital-intensive infrastructure investment tends to generate near-term employment opportunities for men. But expanded public services, such as transport, may facilitate women's paid employment, potentially more so than men's because men face fewer time and mobility constraints.

Moving to the structural variables, manufacturing exports as a share of manufacturing imports ( $\mathrm{Mfg} X / M$ ) is not statistically significant in any of the employment equations. The failure to find a positive effect may reflect the changing capital intensity of manufacturing production in the region. As noted, Tejani and Milberg (2016) have found evidence of defeminization of employment in such industries in middle-income countries.

The terms of trade show inconsistent and statistically insignificant results. For women's relative and absolute employment, there is a positive association in the more limited variable specifications (columns 1,2,5, and 6) but this correlation turns negative when fuel and ores exports as a share of merchandise exports (Fuel \& ores/X) and public investment as a share of GDP are added. Restricting the sample to be the same across specifications does not change these results. What does change results is dropping fuel and ores, suggesting that there is some relationship between terms of trade and fuel exports that affects these results (their correlation coefficient is 0.33 ).

The impact of fuel and ores on the terms of trade coefficient is not surprising given that the former has a strong positive association with women's relative employment. To get a sense of magnitude, a one-standard-deviation increase from the median (we take the median as it is lower than the mean) yields an 8.3 percent increase in the ratio of female-to-male employment, with a 7.5 percent increase in women's employment and a negligible decline in men's employment. It is also important to note that the big fuel exporters in the group are not exerting undue influence; Chile is not included in the sample because there are no data on public investment, and we have only a few observations for Venezuela.

Considering the substantive meaning of these results, the positive correlation with women's employment may seem surprising because fuel and ore industries are capital-intensive, and we would expect their expansion to exert a stronger positive effect on men's employment than women's. However, these results are consistent with Dutch Disease-type effects on employment, whereby the expansion of resource-intensive production lowers labor demand in other industrial sectors, many of which employ men. Moreover, to the extent that the income generated by the expansion of fuel and ores exports raises the relative demand for non-tradable services and imported manufactures, 
both effects (declining industrial labor demand and increasing demand for non-tradable services and imports) could result in raising the relative demand for women workers. Such an outcome may reflect the pairing of deindustrialization and informalization that commodity-price booms coupled with trade liberalization can bring. These results are worrying in terms of the prospects for industrialization and creating high-productivity employment for both women and men.

The last employment variable is per-capita GDP growth, which is not positively associated with women's relative or absolute employment. Whereas in Asian labor-intensive export manufacturing economies, women's share of employment tends to rise with growth, this does not occur in Latin America. Fixed effects results show a positive and weakly significant (but economically small) correlation with men's employment, but this association falls away once we control for the endogeneity of GDP growth.

Turning now to Table 3, where the dependent variable is unemployment, we first note that these results are less robust than those for employment. One explanation for this is the variation in the way unemployment is measured across the region and over time within countries (Ball et al. 2011). Series covering different age groups and different definitions of unemployment are used, with some counting discouraged workers and some not. Even with these caveats, however, it is clear that there are fewer differences between women's and men's unemployment than their employment, as evidenced by the similarities between the results on women's and men's absolute unemployment (columns 5-12), which fail to show up as statistical differences in the female-to-male specifications (columns 1-4).

Beginning with social and labor market policy, social spending as a share of GDP does not significantly impact unemployment. However, the minimum wage is negatively correlated with both women's and men's unemployment, with impacts of similar magnitudes. A one-standard-deviation increase in the minimum wage as a share of the average wage is associated with between 9.7 and 10.3 percent lower unemployment for women, and between 10.7 and 12.8 percent lower unemployment for men. The magnitude of this impact is higher than that for employment for both women and especially men. That higher minimum wages are not only consistent with higher employment, but are also associated with lower unemployment, is a strong indicator that raising minimum wages is a particularly effective public policy stance.

On the macro policy variables, the real exchange-rate results are not robust, and do not change when we drop Venezuela from the sample, as they do for employment. On the other hand, higher real interest rates appear to lower women's relative unemployment rates via lowering unemployment for women. A one-standard-deviation increase in the real interest rate lowers women's relative unemployment between 4.1 and 4.7 percent. This result may seem counter-intuitive: Why would higher real interest rates be associated with lower unemployment for women? One possibility is that, if men tend to work in more interest-rate-sensitive industries than women, higher rates may induce these firms to seek cost savings via turning to lower-wage women workers, thereby lowering women's unemployment. The lack of statistical significance on the employment results in Table 2 is consistent with this explanation. However, it is difficult to make a clear statement based exclusively on these results; they should instead serve as a starting point for further research.

The impact of public investment as a share of GDP is large and statistically significant for women's unemployment. A one-standard-deviation in public investment is associated with a decline of between 10 and 13 percent in women's unemployment, and a decrease of between 5.5 and 8.2 percent in men's unemployment - though the statistical significance is much weaker here. The change in women's relative 
employment is not statistically significant, however. Spending on public investment, then, is associated with lower unemployment and higher employment for both women and men.

The macro structural variables perform differently for unemployment than for employment. Fuel and ores as a share of merchandise exports is not significant, but both the ratio of manufacturing exports to imports and the terms of trade, which were not significant in the employment equations of Table 2, are economically and statistically significant for both women and men. A one-standard-deviation increase in manufactured goods as a share of exports is associated with an average increase of 19.8 percent in women's unemployment, and 18.4 percent in men's. The strong positive association between this measure of industrial upgrading and unemployment is perhaps related to evidence that today's developing countries have started to deindustrialize, reaching peak manufacturing employment at much earlier stages of development than advanced economies did, with openness to international trade a key mechanism for these dynamics (Rodrik 2015).

For the terms of trade, the unemployment results are also more clear and robust relative to the results for employment. Higher terms of trade are associated with more unemployment for women and men, and statistically the gender effects seem to be equivalent. For women, a one-standard-deviation change in the terms of trade (19 percent) raises women's unemployment between 7 and 15 percent, and men's between 6 and 12 percent. These are very large effects. Considering that commodity price changes are so important in driving the terms of trade in the region, especially over the last decade, these results present strong evidence for Dutch Disease-type effects on unemployment, as well as suggest that commodity-price booms may throw people out of work due to import competition. Regardless, the results are similar in terms of gender.

Contrary to the results for employment in Table 2, GDP growth shows strong impacts across the unemployment specifications. While GDP growth lowers both women's and men's unemployment, it lowers men's by more. A one percentage point increase in GDP growth lowers women's unemployment between 1 and 2 percent, and men's a little more than 2 percent. Controlling for the endogeneity of growth does not change the results substantially. Overall, then, we find that GDP growth can be important for lowering unemployment, particularly for men.

Several notable patterns emerge from these results. Both social expenditures and minimum wages are positively associated with greater gender equality in employment as a result of improvements in women's employment (as opposed to a deterioration in men's). Unemployment rates decline for both women and men with higher minimum wages as well, with similar impacts by gender. All of these effects are economically large and statistically robust, suggesting that social and labor market policies provide effective mechanisms not only for enhancing gender equality in employment outcomes, but for improving employment prospects for both women and men.

In terms of macro policies, real exchange rates proffer a policy vehicle for stimulating women's employment. This nexus is straightforward. Real depreciations that lower the price of export goods stimulate employment-generating demand for export goods. Also, in female-dominated labor-intensive industries, they reduce the pressure to lower wages as a means to achieve competitiveness. Public investment benefits both women and men, though there is some evidence that women's employment increases more from such investment.

The variables for economic structure suggest an underlying story about deindustrialization and trade, perhaps related to Dutch Disease dynamics introduced by the commodity-price boom of the 2000s. Fuel exports are positively associated with women's employment but not with men's. Terms-of-trade increases and a higher 
share of manufacturing exports relative to imports are both associated with higher unemployment rates, of roughly equivalent magnitudes, for both women and men. Reconciling these results one can begin to see a story about the effects of trade and global prices on labor markets, though our model did not directly explore these questions.

Notable in these econometric results is that GDP growth does not exhibit robust positive and significant gender effects on employment, consistent with the findings of Seguino (2007). We do find that GDP growth is associated with lower unemployment, however, with a stronger effect for men than women and thus associated with greater gender inequality in unemployment.

\section{CONCLUDING REMARKS}

The increases in growth and declines in inequality and poverty that characterized much of the last decade in Latin America are promising indicators of a structural break with the crises of the 1980s and the lackluster economic record of the 1990s. In this paper, we take stock of these changes on gender inequality in economic opportunities. Some clear themes emerge from this analysis. Both social spending and higher minimum wages are positive stand-outs in improving employment opportunities for women, and higher minimum wages are associated with lower unemployment for both women and men. Public investment is also associated with more employment for women and men, and women's increases are larger than those of men.

The findings on social policy spending parallel those on the determinants of decreasing household income inequality in the literature, though our focus on employment and inclusion of public investment uncovers more promising relationships between public spending and well-being via the employment channel. However, given increasing pressures on public budgets throughout the region, the capacity of labor market policy to bring about more equality indicates that advancing gender equality need not be fully predicated on the short-term financial solvency of governments.

Regarding gender-equalizing macro policy-making, globalization policies in the Latin American region appear to be more geared towards managing global capital flows and domestic inflation than creating employment, particularly for women (Braunstein 2012). The continued promotion of liberalized trade and capital flows, despite their association with appreciated real exchange rates, are consistent with such an interpretation. Understanding the role of changes in the terms of trade in terms of public budgets, the real exchange rate, and industrial structure would also be important in this regard. At the core is the absence of widespread, employment-generating industrial and development policies. Governments have proceeded farther in increasing and strategically targeting social spending, as evidenced by the role of social public expenditures in the regressions. But the evidence provided in this paper suggests that the effect of various development paths, as reflected in our measures of macroeconomic structure, on gender inequality in economic opportunity has been less palpable. Given the recessionary turn in many economies in the region, these questions are all the more pressing.

While our results offer some evidence on how a variety of macro-level policies and economic structures influence gender equality as measured by employment and unemployment rates, there remains a question of how other types of inequality have changed. In particular, we know that, on a broad range of human capability measures, achievements in the 2000s have not been nearly as substantial for indigenous and Afro-descendent populations as they have been for women or poor households in general (Ñopo 2012). In order to fully understand and ultimately redress the structural 
causes of inequality, it is essential to incorporate an analysis of inequality based on ethnicity as well as income and gender, and how these different facets of inequality interact with one another.

\section{ACKNOWLEDGEMENTS}

We are grateful for helpful comments from Sarah Gammage, an anonymous referee, and the editors of Review of Keynesian Economics, and for financial support from the International Labour Organization.

\section{REFERENCES}

Agénor, P.R. and O. Canuto (2012), 'Access to infrastructure and women's time allocation: evidence and a framework for policy analysis,' Fondation Pour Les Etudes et Recherches sur le Developpement, Working paper/P45.

Azevedo, J., M. Dávalos, C. Diaz-Bonilla, B. Atuesta, and R. Casteñeda (2013), 'Fifteen years of inequality in Latin America: how have labor markets helped?' World Bank Policy Research Working Paper 6384.

Ball, L., N. de Roux, and M. Hofstetter (2011), 'Unemployment in Latin America and the Caribbean,' IMF Working Paper WP/11/252.

Barrientos, A. (2014), 'On the distributional implications of social protection reforms in Latin America,' in G.A. Cornia (ed.), Falling Inequality in Latin America, Oxford: Oxford University Press, pp. 340-360.

Barro, R. and J.-W. Lee (2010), 'A new data set of educational attainment in the world, 1950-2010,' Journal of Development Economics, 104, 184-198.

Birdsall, N., N. Lustig, and D. McLeod (2013), 'Declining inequality in Latin America: some economics, some politics,' in P. Kingstone and D. Yasher (eds), Routledge Handbook of Latin American Politics, New York and London: Routledge, pp. 158-180.

Braunstein, E. (2012), 'Neoliberal development macroeconomics: a consideration of its gendered employment effects,' UNRISD Gender and Development Programme Paper No 14.

Braunstein, E., S. Gammage, and S. Seguino (2015), 'Equidad de género, en las oportunidades económicas en América Latina, 1990-2010,' Revista de Economía Crítica, 18, 92-112.

Cornia, G.A. (2010), 'Income distribution under Latin America's new left regimes,' Journal of Human Development and Capabilities, 11(1), 85-114.

Cornia, G.A. (2014), 'Inequality trends and their determinants: Latin America over 1990-2010,' in G.A. Cornia (ed.), Falling Inequality in Latin America, Oxford: Oxford University Press, pp. $23-48$.

Cornia, G.A., J.C. Gómez-Sabaini, and B. Martorano (2011), 'A new fiscal pact, tax policy changes and income inequality,' UNU-WIDER Working Paper No 2011/70.

Costa, J., E. Silva, and F. Vaz (2009), 'The role of gender inequalities in explaining income growth, poverty and inequality: evidence from Latin American countries,' International Policy Centre for Inclusive Growth, Working Paper 52.

Cunningham, W. (2007), Minimum Wages and Social Policy: Lessons from Developing Countries, Washington, DC: World Bank.

Damill, M. and R. Frenkel (2014), 'Macroeconomic policies, growth, employment, and inequality in Latin America,' in G.A. Cornia (ed.), Falling Inequality in Latin America, Oxford: Oxford University Press, pp. 213-233.

Gammage, S. (2010), 'Time pressed and time poor: unpaid household work in Guatemala,' Feminist Economics, 16(3), 79-112.

Keifman, S. and R. Maurizio (2014), 'Change in labour market conditions and politics: their impact on wage inequality during the last decade,' in G.A. Cornia (ed.), Falling Inequality in Latin America, Oxford: Oxford University Press, pp. 251-273. 
Klasen, S. and F. Lamanna (2009), 'The impact of gender inequality in education and employment on economic growth: new evidence for a panel of countries,' Feminist Economics, 15(3), 91-132.

Lopez-Calva, L. and N. Lustig (2010), Declining Inequality in Latin America: A Decade of Progress? Washington, DC: Brookings Institution and UNDP.

Lopez-Calva, L., N. Lustig, and E. Ortiz-Juarez (2015), 'A long-term perspective on inequality and human development in Latin America,' Journal of Human Development and Capabilities, 16(3), 319-323.

Lustig, N., L. López-Calva, E. Ortiz-Juarez, and C. Monga (2016), 'Deconstructing the decline in inequality in Latin America,' in K. Basu and J. Stiglitz (eds), Inequality and Growth: Patterns and Policy, London: Palgrave Macmillan, pp. 212-247.

Madrid, R., W. Hunter, and K. Weyland (2010), 'The policies and performance of the contestatory and moderate left,' in K. Weyland, R. Madrid, and W. Hunter (eds), Leftist Governments in Latin America: Successes and Shortcomings, Cambridge, UK: Cambridge University Press, pp. 140-180.

McLeod, D. and N. Lustig (2010), 'Inequality and poverty under Latin America's new left regimes,' Fordham University Department of Economics Discussion Paper No 2010-13, December, Bronx, NY.

Molyneux, M. (2007), 'Change and continuity in social protection in Latin America: mothers at the service of the state?' UNRISD Gender and Development Programme Paper Number 1.

Nopo, H. (2012), New Century, Old Disparities: Gender and Ethnic Earnings Gaps in Latin America and the Caribbean, Washington, DC: Inter-American Development Bank and World Bank.

Ocampo, J.A. (2007), 'The macroeconomics of the Latin American economic boom,' CEPAL Review, 93, 7-28.

Ocampo, J.A. and J. Vallejo (2012), 'Economic growth, equity and human development in Latin America,' Journal of Human Development and Capabilities, 21(1), 107-133.

Rodriguez, F. and A. Jayadev (2010), 'The declining share of labor income,' Human Development Research Paper 2010/36.

Rodrik, D. (2015), 'Premature deindustrialization,' Working Paper No 20935, NBER, Cambridge, MA.

Rubery, J. and D. Grimshaw (2011), 'Gender and the minimum wage,' in S. Lee and D. McCann (eds), Regulating for Decent Work: New Directions in Labour Market Regulation, London: Palgrave, pp. 226-254.

Seguino, S. (2007), 'The great equalizer? Globalization effects on gender equity in well-being in Latin America and the Caribbean,' in A. Shaikh (ed.), Globalization and the Myth of Free Trade, London: Routledge, pp. 177-214.

Seguino, S. (2010), 'Gender, distribution, and balance of payments constrained growth in developing countries,' Review of Political Economy, 22(3), 373-404.

Seguino, S. (2016), 'Global trends in gender equality,' Journal of African Development, 18(1), $1-30$.

Solt, F. (2016), 'The standardized world income inequality database,' Social Science Quarterly, 97, SWIID Version 5.1, July.

Staiger, D. and J.H. Stock (1997), 'Instrumental variables regression with weak instruments,' Econometrica, 65(3), 557-586.

Székely, M. and P. Mendoza (2015), 'Is the decline in inequality in Latin America here to stay?' Journal of Human Development and Capabilities, 16(3), 397-419.

Tejani, S. and W. Milberg (2016), 'Global defeminization? Industrial upgrading, occupational segmentation and manufacturing employment in middle-income countries,' Feminist Economics, 22(2), 24-54.

Tsounta, E. and A. Osueke (2014), 'What is behind Latin America's declining income inequality?' IMF Working Paper WP/14/124. 
330 Review of Keynesian Economics, Vol. 6 No. 3

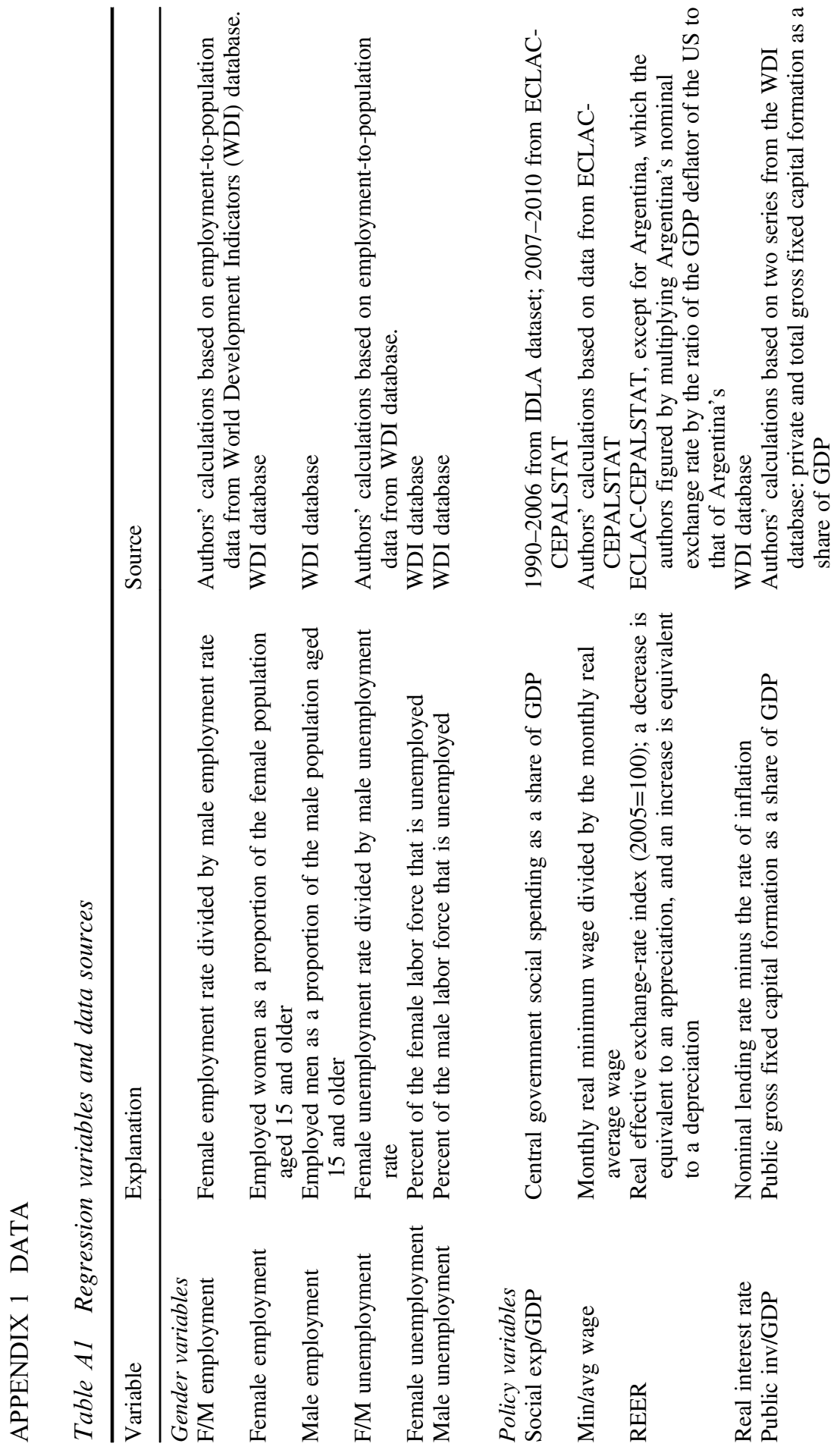


Gender employment inequality in Latin America, 1990-2010 331

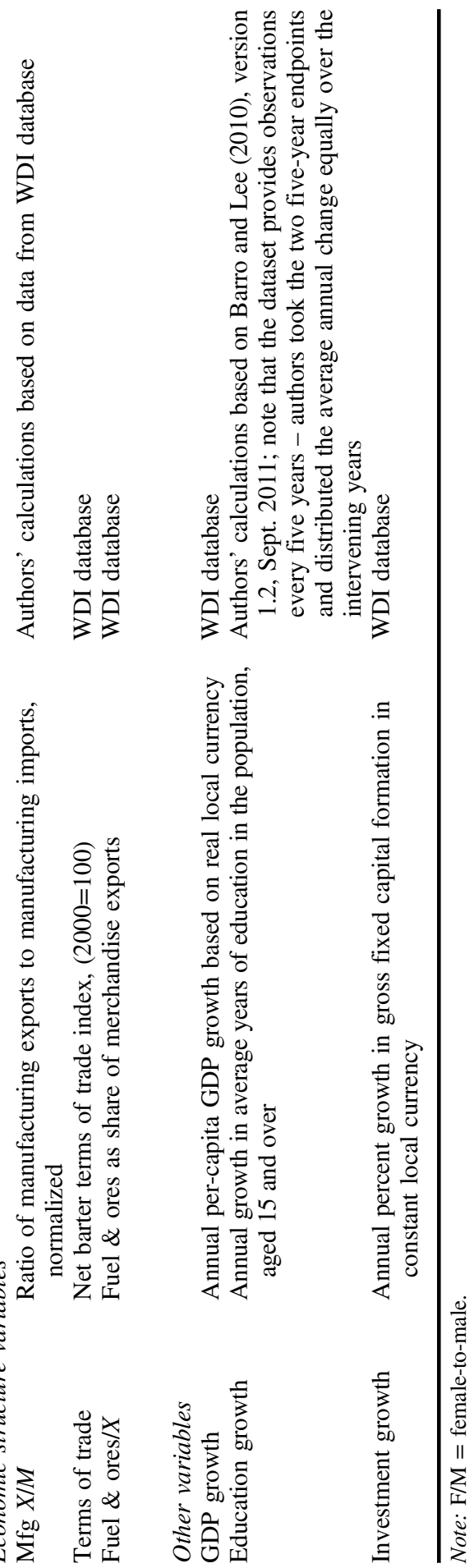

(C) 2018 The Author 
332 Review of Keynesian Economics, Vol. 6 No. 3

\section{APPENDIX 2}

Table A2 First stage regression results

\begin{tabular}{lcc}
\hline & \multicolumn{2}{c}{ Dependent variable: per-capita GDP growth } \\
\cline { 2 - 3 } & $(1)$ & $(2)$ \\
\hline Investment growth & $0.175^{* * *}$ & $0.178^{* * *}$ \\
& $(0.0225)$ & $(0.0300)$ \\
Education growth & 0.178 & 0.143 \\
& $(0.173)$ & $(0.283)$ \\
Social exp/GDP & $1.561^{* *}$ & $2.244^{*}$ \\
& $(0.698)$ & $(1.098)$ \\
Min/avg wage & $2.021^{*}$ & 1.823 \\
& $(1.019)$ & $(1.165)$ \\
Mfg X/M & -0.246 & 0.146 \\
& $(0.786)$ & $(0.875)$ \\
Terms of trade & 1.748 & $2.248^{*}$ \\
& $(1.554)$ & $(1.212)$ \\
REER & 0.624 & 0.716 \\
& $(1.303)$ & $(1.723)$ \\
Real interest rate & -0.00879 & -0.00651 \\
& $(0.0117)$ & $(0.0106)$ \\
Public inv/GDP & - & 0.0272 \\
& - & $(0.976)$ \\
Fuel \& ores/X & - & 0.761 \\
& - & $(0.524)$ \\
Observations & 272 & 183 \\
$R$-squared & 0.613 & 0.640 \\
Countries & 18 & 13 \\
\hline
\end{tabular}

Notes: The first stage for the 2SLS regressions is the same across models, except for some variation in the sample observations. The results above correspond to Table 2 columns (2) and (4), and are representative of the results across different samples. For further details, see notes to Table 2 . 